\title{
1 Pre- and post-production processes along supply chains 2 increasingly dominate GHG emissions from agri-food systems 3 globally and in most countries
}

4 Francesco N. Tubiello ${ }^{1}$, Kevin Karl ${ }^{1,2}$, Alessandro Flammini ${ }^{1,3}$, Johannes Gütschow ${ }^{4}$, Griffiths

5 Obli-Laryea ${ }^{1}$, Giulia Conchedda ${ }^{1}$, Xueyao $\mathrm{Pan}^{1}$, Sally Yue $\mathrm{Qi}^{2}$, Hörn Halldórudóttir

6 Heiðarsdóttir ${ }^{1}$, Nathan Wanner ${ }^{1}$, Roberta Quadrelli ${ }^{5}$, Leonardo Rocha Souza ${ }^{6}$, Philippe Benoit ${ }^{2}$, 7 Matthew Hayek ${ }^{7}$, David Sandalow ${ }^{2}$, Erik Mencos-Contrera ${ }^{8,9}$, Cynthia Rosenzweig ${ }^{9,8}$, Jose'

8 Rosero Moncayo $^{1}$, Piero Conforti ${ }^{1}$ and Maximo Torero ${ }^{1}$

$9 \quad{ }^{1}$ Food and Agriculture Organization, Rome, Italy

$10 \quad{ }^{2}$ Center on Global Energy Policy, Columbia University, New York, USA

$11{ }^{3}$ United Nations Industrial Development Organization, Department of Environment, Vienna, Austria

$12{ }^{4}$ Potsdam Institute for Global Climate Research, Potsdam, Germany

13 International Energy Agency, Paris, France

$14{ }^{6}$ United Nations Statistics Division, New York, USA

$15{ }^{7}$ Department of Environmental Science, New York University, New York, USA

$16{ }^{8}$ Center of Global Climate Research, Columbia University, New York, USA

$17 \quad{ }^{9}$ NASA Goddard Institute for Space Studies, New York, USA

*Corresponding author: Francesco N. Tubiello, francesco.tubiello@fao.org

Abstract. We present results from the FAOSTAT agri-food systems emissions database, relative to 236 countries and territories and over the period 1990-2019. We find that in 2019, world-total food systems emissions were 16.5 billion metric tonnes $\left(\mathrm{Gt} \mathrm{CO}_{2 \mathrm{eq}} \mathrm{yr}^{-1}\right)$, corresponding to $31 \%$ of total anthropogenic emissions. Of the agri-food systems total, global emissions within the farm gate -from crop and livestock production processes including on-

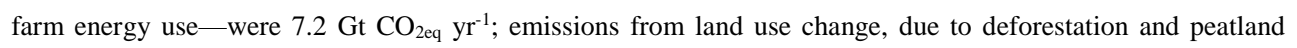
degradation, were $3.5 \mathrm{Gt} \mathrm{CO}_{2 \mathrm{eq}} \mathrm{yr}^{-1}$; and emissions from pre- and post-production processes -manufacturing of fertilizers, food processing, packaging, transport, retail, household consumption and food waste disposal—were $5.8 \mathrm{Gt} \mathrm{CO}_{2 \mathrm{eq}} \mathrm{yr}^{-1}$. Over the study period 1990-2019, agri-food systems emissions increased in total by $17 \%$, largely driven by a doubling of emissions from pre- and post-production processes. Conversely, the FAO data show that since 1990 land use emissions decreased by $25 \%$, while emissions within the farm gate increased only $9 \%$. In 2019, in terms of single GHG, pre- and post- production processes emitted the most $\mathrm{CO}_{2}\left(3.9 \mathrm{Gt} \mathrm{CO}_{2} \mathrm{yr}^{-1}\right)$, preceding land use change (3.3 $\left.\mathrm{Gt} \mathrm{CO}_{2} \mathrm{yr}^{-1}\right)$ and farm-gate $\left(1.2 \mathrm{Gt} \mathrm{CO}_{2} \mathrm{yr}^{-1}\right)$ emissions. Conversely, farm-gate activities were by far the major emitter of methane ( $\left.140 \mathrm{Mt} \mathrm{CH}_{4} \mathrm{yr}^{-1}\right)$ and of nitrous oxide $\left(7.8 \mathrm{Mt} \mathrm{N}_{2} \mathrm{O} \mathrm{yr}^{-1}\right)$. Preand post- processes were also significant emitters of methane (49 $\mathrm{Mt} \mathrm{CH}_{4} \mathrm{yr}^{-1}$ ), mostly generated from the decay of solid food waste in landfills and open-dumps. The most important trend over the 30-year period since 1990 highlighted by our analysis is the increasingly important role of food-related emissions generated outside of 
1 and national, from 1990 to 2019. In fact, our data show that by 2019, food supply chains had overtaken farm-gate

2 processes to become the largest GHG component of agri-food systems emissions in Annex I parties (2.2 Gt $\mathrm{CO}_{2 \mathrm{eq}}$

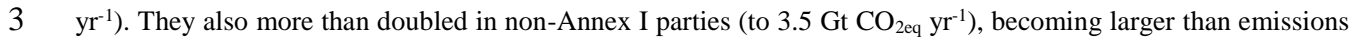

4 from land-use change. By 2019 food supply chains had become the largest agri-food system component in China

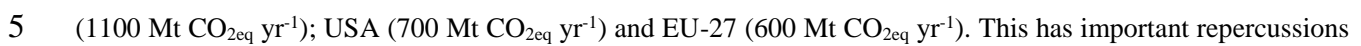

6 for food-relevant national mitigation strategies, considering that until recently these have focused mainly on

7 reductions of non- $\mathrm{CO}_{2}$ gases within the farm gate and on $\mathrm{CO}_{2}$ mitigation from land use change. The information

8 used in this work is available as open data at: https://zenodo.org/record/5615082 (Tubiello et al., 2021d). It is also

9 available to users via the FAOSTAT database (FAO, 2021a), with annual updates.

10 Keywords: Agri-food systems, GHG emissions, farm gate, land use change, supply chains 


\section{1. Introduction}

2 Agriculture is a significant contributor to climate change as well as the economic sectors most at risk from it.

3 Greenhouse gas (GHG) emissions generated within the farm gate by crop and livestock production and related

4 land use change contribute about one-fifth to one-quarter of total emissions from all human activities, when

5 measured in $\mathrm{CO}_{2}$ equivalents (Mbow et al., 2019; Smith et al., 2014; Vermeulen et al., 2012). In terms of single

6 gases, impacts are even starker. Agriculture contribute nearly $50 \%$ of world total anthropogenic methane $\left(\mathrm{CH}_{4}\right)$

7 and $75 \%$ of the total nitrous oxide $\left(\mathrm{N}_{2} \mathrm{O}\right)$ emissions (FAO, 2021b; Gütschow et al., 2021; Saunois, et al., 2020).

8 Once pre- and post-production activities along agri-food systems supply chains are included, food and agriculture

9 activities generate up to one-third of all anthropogenic emissions globally (Rosenzweig et al., 2020; Tubiello et

10 al., 2021a). This larger food systems perspective expands the potential for designing GHG mitigation strategies that can address options in food and agriculture across the entire food system, i.e., over and above the more traditional focus on agricultural production and land use management within countries' Nationally Determined Contributions (FAO, 2019).

14 Significant progress has recently resulted in the development of novel databases with global coverage of countrylevel data on agri-food systems emissions (Crippa et al., 2021a,b; Tubiello et al., 2021a). Tubiello et al. (2021a) in particular provided a mapping of emission categories of the Intergovernmental Panel on Climate Change (IPCC), used for climate reporting by countries of national GHG inventories (NGHGI), to more relevant food and agriculture concepts that, developed by FAO and used to disseminate food and agriculture statistics in FAOSTAT, are more easily understood by farmers and planners in Ministries of Agriculture. Such mapping allows to more adequately capture important aspects of food and agriculture activities within existing climate reporting. Firstly, it expands the IPCC "agriculture" definition to include, in addition to non- $\mathrm{CO}_{2}$ emissions from the farm, also the $\mathrm{CO}_{2}$ generated in drained peatlands on agricultural land (Conchedda and Tubiello, 2020; Drösler et al., 2014) and through energy use in farm operations (FAO, 2020b; Flammini et al., 2021; Sims and Flammini, 2014). Secondly, it usefully disaggregates the 'Land Use, land use change and forestry' (LULUCF) of IPCC (2003) used in NGHGI, by separating out carbon sinks from land-based emissions sources that are more directly linked to food and agriculture, such as those generated by deforestation (Curtis et al., 2020; Tubiello et al., 2021c) and peat fires (Prosperi et al., 2020).

We present and discuss results from the first emissions database in FAOSTAT of food and agriculture emissions. The new database covers, as in previous versions (Tubiello et al., 2013) agriculture production activities within the farm gate and associated land use and land use change emissions on agricultural land. Importantly, it also includes estimates of emissions from pre- and post-production processes along food supply chains, including: energy use within the farm gate, food processing, domestic and international food transport, retail, packaging, household consumption and food waste disposal. The new FAOSTAT database provides information of emissions of the four main GHG gases $\mathrm{CO}_{2}, \mathrm{CH}_{4}, \mathrm{~N}_{2} \mathrm{O}$ and F-gases, as well as their combined $\mathrm{CO}_{2}$ eq levels, by country, over the period 1990-2019. We examine new results and discuss how they can inform national mitigation strategies that are relevant to food and agriculture in countries, regionally and globally. 
1 the first two - generated by crop and livestock production activities within the farm gate and by the conversion of

2 natural ecosystems to agriculture, such as deforestation and peatland degradation — have been long established and

3 data are regularly disseminated in FAOSTAT (FAO, 2021; Tubiello, 2019). This paper adds emission along food

4 supply chains outside of agricultural land, including those generated from energy use in fertilizer manufacturing;

5 food processing; packaging; transport; retail; household consumption; and waste disposal.

$6 \quad 2.1$ Mapping Agri-food Systems Components

7 Emissions data are organized in IPCC emissions categories: Energy; Industrial Processes and Product Use (IPPU,

8 henceforth referred to as Industry); Waste; Agriculture; Land Use, Land Use Change and Forestry (LULUCF);

9 and Other. IPCC sectors and sub-sectors are mapped to FAO categories relevant to food and agriculture, in line with recent work (Tubiello, 2021a), with extensions made to cover all IPCC sectors with relevant food systems activities (Fig. 1). The methods applied herein cover a large component of food supply chain processes. It does not cover by design embedded energy in machinery and upstream emissions associated with oil and gas supply chains.

\subsection{Emissions Estimates}

We provide here the basic estimation methods used for this work, while referring the interested reader to a series of technical papers that document the underlying methodologies in full, detailing all coefficients and data sources used to estimate emissions from energy use in fertilizers manufacturing, food processing, transport, retail, household consumption, waste disposal (Tubiello et al., 2021b; Karl and Tubiello, 2021a, b); as well as energy use on the farm (Flammini et al., 2021). More generally, a step-wise approach was followed for the estimation of agrifood systems emissions: Step 1 identified, for each food systems component, the relevant international statistics needed to characterize country-level activity data (AD). Step 2 determined the food-related shares of the activity data $\left(\mathrm{AD}_{\text {food }}\right)$ and assigns relevant $\mathrm{GHG}$ emission factors $(\mathrm{EF})$ to each activity. Step 3 implemented the generic IPCC method for estimating GHG emissions $\left(\mathrm{E}_{\text {food }}\right)$, using inputs of activity data and emission factors from the first two steps, as follows:

$$
E_{f o o d}=E F^{*} A D_{\text {food }}
$$

Finally, Step 4 imputed any missing agri-food systems emissions data by component, using as input PRIMAP, a complete dataset of emissions estimates for all IPCC sectors, by country, covering the period 1990-2019 (Gütschow et al., 2021). The PRIMAP data compile all available information on GHG emissions by country, including from official reporting. They were used internationally as the basis for an early, first-order estimate of agri-food systems shares in total GHG emissions (IPCC, 2019). Additionally, they were recently used in a UNFCCC Synthesis Report (UNFCCC, 2021) to assess world GHG emissions from all sectors in preparation of a stock take exercise that will be undertaken in 2022-203 to assess countries' performance against their mitigation commitments under the Paris Agreement.

\subsection{Data uncertainty and limitations}

\subsubsection{Boundaries} $30-70 \%$ across many processes (Tubiello, 2019). The uncertainties in the estimates of pre- and post-production activities described herein are less documented. On the one hand, uncertainties in underlying energy activity data 
1 and emissions factors are likely lower than for the other two components. On the other, the relative novelty in

2 estimating food system shares for a range of activity data makes our estimates more uncertain, with heavy reliance

3 on literature results from a subset of countries or regions that are necessarily extended to the rest of the world (Karl

4 and Tubiello, 2021a). In addition, it should be noted that the processes covered herein do not span all processes

5 attributable to agri-food systems. In particular, the scope of this work does not include, by design, upstream GHG

6 emissions in the fuel chain, such as petroleum refining, as well as a methane leaks during extraction processes and

7 piping. These are expected to be not negligible if considered. Conversely, processes such as F-gas emissions from

8 household refrigeration and from climate-controlled transportation were not included for lack of available country-

9 level data and estimation methods. Emissions from pesticide manufacturing were also not included due to the

10 paucity of information and methodologies for their estimation, in contrast to advanced work in fertilizers

11 manufacturing (Brentrup et al., 2016; Brentrup et al., 2018; IFS, 2019)

\section{$12 \quad 2.3 .2$ Uncertainty}

Significant errors may be introduced by the use of sub-regional and regional coefficients, given the diversity in food system typology and their dependence on physical geography and national socio-economic drivers. These limitations nonetheless reflect the paucity of activity data available to describe agri-food systems components and their trends, globally and regionally. While knowledge and data exist for regions and countries such as the EU, USA China, and India, much remains to be done in terms of regional and country specific coverage. generic coefficients in the face of natural spatial and temporal variability characterizing the underlying bio-physical processes. More detailed information on uncertainties associated with emission factors and activity data can be found in the IPCC guidelines (2006).

\subsubsection{Areas for Advancement}

Work towards estimating agri-food systems emissions at the country level can be advanced in several ways. The present approach could be expanded on by including other country- and region-specific studies that estimate trends in energy consumption across a range of similar activities as proxies - whether or not they are distinctly related to food. Furthermore, other data sources could help explain and estimate variations in agri-food systems between countries, such as: GDP per capita, urbanization levels, proxies for infrastructure and industrial development, and geographic and climate considerations. The development of a methodology to estimate emissions from pesticides could be explored, as it would help complement the understanding of emissions associated with chemical use in agriculture, in addition to fertilizers. Emissions from machinery manufacturing and from upstream GHG emissions in the fuel chain could also be added to further refine the analysis. This work could be further expanded by focusing on specific food commodities - requiring an additional focus on international trade and on supply and demand patterns (Dalin and Rodríguez-Iturbe, 2016). Such analysis would ultimately enable consumers to understand the full carbon footprint of particular commodities across global supply chains, which can facilitate GHG mitigation actions taken at the consumer level (Poore and Nemecek, 2018). Furthermore, it would be also useful to further investigate the increasing role of bioenergy and renewables as important mitigation opportunities in the food sector (Clark et al., 2020, JRC, 2015; Pablo-Romero et al., 2017; Wang, 2014). 


\section{Data availability}

2 The GHG emission data presented herein cover the period 1990-2019, at the country level, with regional and global

3 aggregates. They are available as open data at: https://zenodo.org/record/5615082 (Tubiello et al., 2021d) and via

4 the FAOSTAT (FAO, 2021a) database.

\section{Results}

\section{$6 \quad 3.1$ Global trends}

7 In 2019 world-total agri-food systems emissions were 16.5 billion metric tonnes $\left(\mathrm{Gt} \mathrm{CO}_{2 \mathrm{eq}} \mathrm{yr}^{-1}\right)$, corresponding to $831 \%$ of total anthropogenic emissions (Tab. 1). Of the food systems total, global emissions within the farm gate -

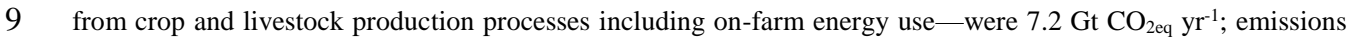

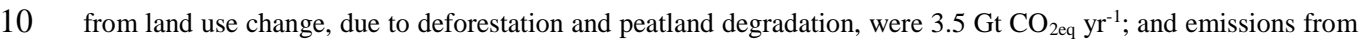
11 pre- and post-production processes - manufacturing of fertilizers, food processing, packaging, transport, retail, 12 household consumption and food waste disposal-were $5.8 \mathrm{Gt} \mathrm{CO}_{2 \mathrm{eq}} \mathrm{yr}^{-1}$. Over the study period 1990-2019, agri13 food systems emissions increased in total by 17\%, though they have remained rather constant since about 2006 14 (Fig. 2). These trends were largely driven by a doubling of emissions from pre- and post-production processes, 15 while land use emissions decreased by $25 \%$ and farm gate increased only $9 \%$. In terms of single GHG, pre- and 16 post- production processes emitted the most $\mathrm{CO}_{2}\left(3.9 \mathrm{Gt} \mathrm{CO}_{2} \mathrm{yr}^{-1}\right)$ in 2019 , preceding land use change ( $3.3 \mathrm{Gt}^{\mathrm{CO}_{2}}$ $\left.\mathrm{yr}^{-1}\right)$ and farm-gate $\left(1.2 \mathrm{Gt} \mathrm{CO}_{2} \mathrm{yr}^{-1}\right)$ emissions. Conversely, farm-gate activities were by far the major emitter of methane (140 $\mathrm{Mt} \mathrm{CH}_{4} \mathrm{yr}^{-1}$ ) and of nitrous oxide $\left(7.8 \mathrm{Mt} \mathrm{N}_{2} \mathrm{O} \mathrm{yr}^{-1}\right.$ ). Pre-and post- processes were also significant emitters of methane (49 $\mathrm{Mt} \mathrm{CH}_{4} \mathrm{yr}^{-1}$ ), mostly generated from the decay of solid food waste in landfills and opendumps.

Emissions from within the farm gate and those due to related land use processes, including details of their subcomponents, have been discussed in Tubiello et al. (2021a) and are regularly presented within FAOSTAT statistical briefs (e.g., FAO, 2020a). Here we provide a detailed discussion of the components of agri-food systems emissions from pre- and post-production activities along supply chains and their relative contribution to the food system totals (Fig. 3). Our data show that in 2019 emissions from deforestation were the single largest emission component of agri-food systems, at 3,058 $\mathrm{Mt} \mathrm{CO}_{2} \mathrm{yr}^{-1}$, having decreased 30\% since 1990. The second most important component were non- $\mathrm{CO}_{2}$ emissions from enteric fermentation $\left(2,823 \mathrm{Mt} \mathrm{CO}_{2} \mathrm{eq} \mathrm{yr}\right.$ ), with increases of

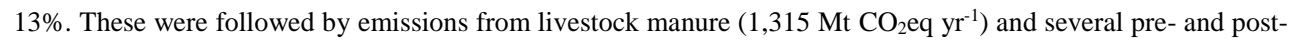
production emissions, including $\mathrm{CO}_{2}$ from household consumption (1,309 ${\mathrm{Mt} \mathrm{CO}_{2} \mathrm{eq} \mathrm{yr}}^{-1}), \mathrm{CH}_{4}$ from food waste disposal (1,278 $\mathrm{Mt} \mathrm{CO}_{2}$ eq yr $\left.{ }^{-1}\right)$, mostly $\mathrm{CO}_{2}$ from fossil-fuel combustion for on-farm energy use $\left(1,021 \mathrm{Mt} \mathrm{CO}_{2} \mathrm{eq}\right.$ $\mathrm{yr}^{-1}$ ), and $\mathrm{CO}_{2}$ and F-gases emissions from food retail (932 $\left.\mathrm{Mt} \mathrm{CO}_{2} \mathrm{eq} \mathrm{yr}^{-1}\right)$. Importantly, our data show that growth in pre- and post-production components was particularly strong, with emissions from retail increasing from 1990 to 2019 by more than seven-fold, while emissions from household consumption more than doubled over the same period.

\subsection{Regional Trends}

Our results indicate significant regional variation in terms of the composition of agri-food systems emissions by component (Fig. 4). Specifically, in terms of total agri-food systems emissions in 2019, Asia had the largest contribution, at $7 \mathrm{Gt} \mathrm{CO}_{2} \mathrm{eq} \mathrm{yr}{ }^{-1}$, followed by Africa $\left(2.7{\mathrm{Gt} \mathrm{CO}_{2} \mathrm{eq} \mathrm{yr}}^{-1}\right)$, South America $\left(2.4 \mathrm{Gt}_{\mathrm{CO}_{2}} \mathrm{eq} \mathrm{yr}{ }^{-1}\right)$ and 
1 Europe (2.1 $\left.\mathrm{Gt} \mathrm{CO}_{2} \mathrm{eq} \mathrm{yr}{ }^{-1}\right)$. North America $\left(1.5 \mathrm{Gt} \mathrm{CO}_{2} \mathrm{eq} \mathrm{yr}^{-1}\right)$ and Oceania $\left(0.3 \mathrm{Gt} \mathrm{CO}_{2} \mathrm{eq} \mathrm{yr} \mathrm{yr}^{-1}\right)$ were the smallest

2 emitters among regions (Fig. 4). Focusing on GHG emissions beyond agricultural land, pre- and post-production

3 emissions in 2019 were largest in Asia (2.9 $\left.\mathrm{Gt} \mathrm{CO}_{2} \mathrm{eq} \mathrm{yr}^{-1}\right)$, followed by Europe and North America (0.8-1.1 Gt

$4 \mathrm{CO}_{2}$ eq $\mathrm{yr}^{-1}$ ). Regions also varied in terms of how agri-food systems components contributed to the total (Tab. 2).

5 In 2019, pre- and post- production emissions were the largest food systems contributor in Europe (55\%), North

6 America (52\%) and Asia (42\%). Conversely, they were smallest in Oceania (23\%), Africa (14\%) and South

7 America (12\%). Additionally, the contribution of pre- and post-production processes along food supply chains

8 significantly increased since 1990, when in no region they were the dominant emissions component. Since then,

9 they doubled in all regions except in Africa-where it remained below $15 \%$.

Finally, the data show which pre- and post-production process was most important by region (Tab. 2). In 2019, food household consumption was the dominant process outside of agricultural land emissions in Asia (0.9 Gt $\left.\mathrm{CO}_{2} \mathrm{eq} \mathrm{yr}^{-1}\right)$ and Africa $\left(0.2 \mathrm{Gt} \mathrm{CO}_{2} \mathrm{eq} \mathrm{yr} \mathrm{yr}^{-1}\right)$. Conversely, Europe, Oceania and North America pre- and post-

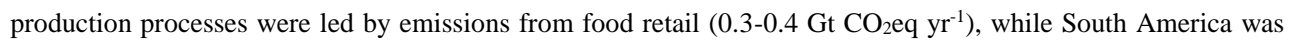
dominated by emissions from food waste disposal $\left(0.2 \mathrm{Gt} \mathrm{CO}_{2} \mathrm{eq} \mathrm{yr}^{-1}\right)$.

\subsection{Country Trends}

Our estimates show a marked variation among countries in terms of total emissions as well as the composition of contributions across farm gate, land use change and pre- and post-processing components (Fig. 5). China had the

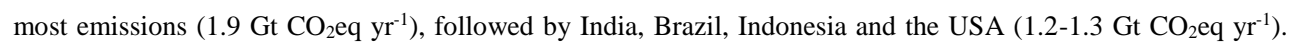
Democratic Republic of Congo (DRC) and Russian Federation followed with 0.5-0.6 Gt $\mathrm{CO}_{2} \mathrm{eq} \mathrm{yr}^{-1}$, followed by

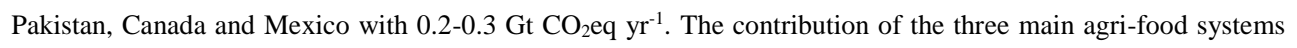
components to the national total differed among countries significantly (Fig. 5). For instance, China and India had virtually no contribution from land use change to agri-food systems emissions. The land use contribution was also minor in the USA, Russian Federation and Pakistan. Conversely, the latter was the dominant emissions component in Brazil, Indonesia and the DRC. Additionally, the new database allowed for an in-depth analysis by country of pre- and post-production emissions along the agri-food chain, highlighting a significant variety in most relevant sub-process contribution (Tab. 3). For the year 2019, pre- and post-production emissions were dominated in China by food household consumption processes (463 $\left.\mathrm{Mt} \mathrm{CO}_{2} \mathrm{eq} \mathrm{yr}^{-1}\right)$, whereas food waste disposal was the dominant pathway in Brazil, Indonesia (77 $\mathrm{Mt} \mathrm{CO}_{2}$ eq yr $\left.\mathrm{yr}^{-1}\right)$, DRC $\left(8 \mathrm{Mt} \mathrm{CO}_{2} \mathrm{eq} \mathrm{yr}^{-1}\right)$, Pakistan $\left(33 \mathrm{Mt} \mathrm{CO}_{2}\right.$ eq yr-1 $)$ and Mexico, (56 $\mathrm{Mt} \mathrm{CO}_{2} \mathrm{eq} \mathrm{yr}^{-1}$ ). Emissions from food retail dominated the pre- and post-production component in the USA (292 $\mathrm{Mt} \mathrm{CO}_{2}$ eq yr $\left.{ }^{-1}\right)$, Russian Federation (177 $\left.\mathrm{Mt} \mathrm{CO}_{2} \mathrm{eq} \mathrm{yr}^{-1}\right)$ and Canada $\left(20 \mathrm{Mt} \mathrm{CO}_{2} \mathrm{eq} \mathrm{yr}^{-1}\right)$. Finally, on-farm energy use was the largest pre- and post-production component in India $\left(205 \mathrm{Mt} \mathrm{CO}_{2} \mathrm{eq}^{-1} \mathrm{r}^{-1}\right.$ ).

\section{Discussion}

The most important trend over the 30-year period since 1990 to present that emerges from our analysis is the increasingly important role of food-related emissions generated outside of agricultural land, in pre- and postproduction processes along food supply chains, at all scales from global, regional and national, from 1990 to 2019. Our data show that by 2019 , food supply chains had overtaken farm-gate processes to become the largest GHG component of agri-food systems emissions in Annex I parties (2.2 $\left.\mathrm{Gt} \mathrm{CO}_{2 \mathrm{eq}} \mathrm{yr}^{-1}\right)$. While farm gate emissions still 
1 chains had become the largest agri-food system component in China (1,100 $\left.\mathrm{Mt} \mathrm{CO}_{2 \mathrm{eq}} \mathrm{yr}^{-1}\right)$; USA (700 $\mathrm{Mt} \mathrm{CO}_{2 \mathrm{eq}}$ $\left.2 \mathrm{yr}^{-1}\right)$ and EU-27 (600 $\left.\mathrm{Mt} \mathrm{CO}_{2 e q} \mathrm{yr}^{-1}\right)$. This has important repercussions for food-relevant national mitigation 3 strategies, considering that until recently these have focused mainly on reductions of non- $\mathrm{CO}_{2}$ gases within the 4 farm gate and on $\mathrm{CO}_{2}$ mitigation from land use change. Importantly, the FAOSTAT database presented here allows for an estimation of the percentage share contribution

6 of food systems emissions in total anthropogenic emissions, by country as well as at regional and global levels, 7 over the period 1990-2019. The FAOSTAT-PRIMAP database covering all sectors which underlies this study 8 estimates total anthropogenic emissions at about $52 \mathrm{Gt} \mathrm{CO}_{2} \mathrm{eq} \mathrm{yr}^{-1}$ without land use, land use change and forestry

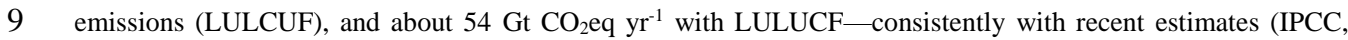
2019). We use the latter figure to compute emissions shares. A number of important issues can be highlighted to this end (Tab. 4 and Fig. 6). First, in terms of CO2eq, the share of world total agri-food systems emissions decreased from $40 \%$ in 1990 to $31 \%$. Thus while it is important to note that one-third of all GHG emissions today are generated by agri-food systems, their shares in total emissions may continue decreasing in the near future. This decreasing trend was driven by trends in large regions with ongoing transformations in their agri-food systems and land use change patterns. For instance, in South America, the region with the highest food systems share over the entire study period (Fig. 6), food shares went from $96 \%$ to $72 \%$ in 2019. In Africa, from 67\% to 57\%, in Asia from $49 \%$ to $24 \%$ and in Oceania from $57 \%$ to $39 \%$. In contrast to these trends however, in regions dominated by modern agri-food systems such as Europe and North America, our data suggest that the overall share of agri-food systems emissions increased from 1990 to 2019, specifically from 24\% to 31\% in Europe and from 17\% to 21\% in North America. Such increases in these two regions were due to a disproportionate increase in emission from pre- and post-production activities, as noted earlier, resulting in addition to doubling absolute emission also doubled their underlying shares (Tab. 4). It is also worth noting that in all regions absolute emissions form pre- and postproduction activities increased from 1990 to 2019, and that such increased in all regions but Africa were accompanied by larger relative shares of this food system component in 2019 compared to 1990.

A final analysis on agri-food systems impacts on total GHG emissions would not be complete without a focus on component gases in addition to quantities expressed in $\mathrm{CO}_{2}$ eq. The FAOSTAT data confirm the trends form 1990 to 2019 seen for total $\mathrm{CO}_{2}$ eq emissions, with important features (Tab. 5). First, the impact of agri-food systems on world total $\mathrm{CO}_{2}$ emissions was $21 \%$ in 2019 (down from $31 \%$ in 1990), a respectable share considering the importance of carbon dioxide in any effective long-term mitigation strategy. While most regions had contributions around this value, ranging 13\%-23\% for North America, Oceania, Europe and Asia, the $\mathrm{CO}_{2}$ contribution of agrifood systems was higher in Africa (52\%) and South America (70\%), largely in relation to the land use change emissions that are still significant therein. Additionally, Europe and North America were the only regions where the $\mathrm{CO}_{2}$ shares actually increased from 1990 to 2019, confirming the growing weight of pre- and post-production processes, which typically involve fossil-fuel energy use. Second, the data highlight the significant contribution of agri-food systems to 2019 world total emissions of $\mathrm{CH}_{4}(53 \%)$ and $\mathrm{N}_{2} \mathrm{O}$ (78\%), also confirmed at regional levels (Tab. 5), linked to farm gate production processes (Tubiello, 2019). Finally, the data highlight a very large increase in agri-food systems contributions of F-gas emissions, which went from near zero in 1990 to more than one-quarter of the world total in 2019 -with larger contributions in many regions. At least with respect to the underlying assumptions made in our methods, such a marked increase was entirely due to strong growth of refrigeration in the food retail sector (Hart et al., 2020; IIR, 2021; Tubiello et al., 2021b). 
1 Another aspect of the dataset underlying this study is that it provides food and agriculture relevant information

2 across IPCC and FAO definitions and classifications. In terms of national GHGH inventories, it is worth pointing

3 out that while agri-food systems were found to be about one-third of total anthropogenic emissions, our data

4 indicated that emissions from land use, land use change and forestry (LULUCF) in 2019 only represented 3-4\%,

5 while emissions from agriculture, forestry and other land use (AFOLU), were a mere $15 \%$ of the total

6 anthropogenic emissions.

75 Conclusions

8 This paper provided details of a new FAOSTAT domain characterizing GHG emissions along the entire agri-food 9 systems chain, including crop and livestock production processes on the farm, land use change activities from the

10 conversion of natural ecosystems to agricultural land, and processes along food supply chains, from input manufacturing to food processing, transport and retail, including household consumption and waste disposal.

The data are provided in open access mode to users worldwide and are available by country over the time period 1990-2019. The major trends identified in this work help identify emissions hotspots across agri-food systems and by country, helping to identify areas for effective mitigation actions in food and agriculture. This work adds to knowledge well established in the literature but limited in terms of datasets to farm gate processes and land use change, by adding a wide range of additional details on emissions from pre- and post-production processes. The new data highlight the increasingly important role that these play in the overall emissions footprint of agri-food systems, reflecting a pattern of development from traditional to modern agri-food systems and overall economic growth. The granularity of the dataset allows, for the first time, to highlight specific processes of importance in specific countries or group of countries with similar characteristics. The relevance of the information being provided cuts across several national and international priorities, specifically those aiming at achieving more productive and sustainable food systems, including in relation to climate change. To this end, the work presented herein completes a mapping of IPCC categories, used by countries for reporting to the climate convention, to food and agriculture categories that are more readily understandable by farmers and ministries of agriculture in countries. This helps better identify agri-food systems entry points within existing and future national determined contributions. Finally, the methodological work underlying these efforts complements and extends recent pioneering efforts by FAO and other groups in characterizing technical coefficients to enable quantifying the weight of agri-food systems within countries' emissions profiles. The next steps in such efforts would need the involvement of interested national and international experts in compiling a first set of coefficients for agri-food systems as a pratical 'agri-food systems annex' to the existing guidelines of the Intergovernmental Panel on Climate Change, providing guidance to countries on how to better characterize food and agriculture emissions within their national GHG inventories.

\section{Disclaimer}

34 The views expressed in this paper are the authors' only and do not necessarily reflect those of FAO, UNSD, UNIDO and IEA.

\section{Acknowledgements}

FAOSTAT is supported by the FAO regular budget, funded by its member countries. We acknowledge the efforts of national experts who provide the statistics on food and agriculture as well as on energy use that are at the basis 


\section{References}

Brentrup, F., Hoxha, A., and Christensen, B. 2016. Carbon footprint analysis of mineral fertilizer production in Europe and other world regions. In 10th International Conference on Life Cycle Assessment of Food.

Brentrup, F., Lammel, J., Stephani, T., and Christensen, B. 2018. Updated carbon footprint values for mineral fertilizer from different world regions. In 11th International Conference on Life Cycle Assessment of Food. https://www.researchgate.net/publication/329774170_Updated_carbon_footprint_values_for_mineral_fertilizer_f rom_different_world_regions

10 Clark, M. A., Domingo, N. G. G., Colgan, K., Thakrar, S. K., Tilman, D., Lynch, J., Azevedo, I. L., \& Hill, J. D. 2020. Global food system emissions could preclude achieving the $1.5^{\circ}$ and $2{ }^{\circ} \mathrm{C}$ climate change targets. Science, 370(6517), 705-708. https://doi.org/10.1126/science.aba7357

Crippa, M., Solazzo, E., Guizzardi, D., Monforti-Ferrario, F., Tubiello, F. N., \& Leip, A. 2021a. Food systems are responsible for a third of global anthropogenic GHG emissions. Nature Food, 1-12. https://doi.org/10.1038/s43016-021-00225-9

Crippa, M., Guizzardi, D., Schaaf, E., Solazzo, E., Muntean, M., Monforti-Ferrario, F., Olivier, J.G.J., Vignati, E. 2021b. Emissions Database for Global Atmospheric Research (EDGAR) v6.0. Available from: https://edgar.jrc.ec.europa.eu/index.php/dataset_ghg60

Curtis, P. G., Slay, C. M., Harris, N. L., Tyukavina, A., \& Hansen, M. C. 2018. Classifying drivers of global forest loss. Science, 361(6407), 1108-1111. https://doi.org/10.1126/science.aau3445

Dalin, C., and Rodríguez-Iturbe, I. 2016. Environmental impacts of food trade via resource use and greenhouse gas emissions. Environmental Research Letters, 11(3), 035012. https://doi.org/10.1088/1748-9326/11/3/035012

Drösler, M., Verchot, L. V., Freibauer, A., Pan, G.Evans, C. D.Borbonniere, R. A., ... Couwenberg, J. 2014. Chapter 2: Drained inland organic soils. In T. Hiraishi, T. Krug, K. Tanabe, N. Srivastava, B. Jamsranjav, M. Fukuda, \& T. Troxler (Eds.), 2013 Supplement to the 2006 IPCC Guidelines for National Greenhouse Gas Inventories: Wetlands (pp. 1-79). IPCC: Switzerland.

FAO, 2014. Opportunities for Agri-Food Chains to become Energy-Smart. Available online at: http://www.fao.org/3/a-i5125e.pdf

FAO. 2020a. Emissions due to agriculture. Global, regional and country trends 2000-2018. FAOSTAT Analytical Brief Series No 18. Rome

FAO. 2020b. FAOSTAT: Energy Use. In: FAO.org [online]. https://www.fao.org/faostat/en/\#data/GN

FAO. 2021a. FAOSTAT: Emissions Shares. In: FAO.org [online]. https://www.fao.org/faostat/en/\#data/EM

FAO. 2021b. FAOSTAT: Emissions Totals. In: FAO.org [online]. https://www.fao.org/faostat/en/\#data/GT

Flammini, A., Pan, X., Tubiello, F.N., Qiu, S.Y., Rocha Souza, L., Quadrelli, R., Bracco, S., Benoit, P. and Sims, R., 2021 (preprint). Emissions of greenhouse gases from energy use in agriculture, forestry and fisheries: 19702019. Earth System Science Data Discussions. Available at https://essd.copernicus.org/preprints/essd-2021-262/

Gütschow J., Jeffery L. and R. Gieseke. 2021. The PRIMAP-hist national historical emissions time series v2.3 (1850-2017). GFZ Data Services. Available from: https://doi.org/10.5880/pik.2019.001

Hart, M., Austin, W., Acha, S., Le Brun, N., Markides, C. N., \& Shah, N. 2020. A roadmap investment strategy to reduce carbon intensive refrigerants in the food retail industry. Journal of Cleaner Production, 275, 123039. https://doi.org/10.1016/j.jclepro.2020.123039

International Fertiliser Society. 2019. The carbon footprint of fertiliser production: regional reference values. Available from: https://www.fertilizerseurope.com/wp-content/uploads/2020/01/The-carbon-footprint-offertilizer-production_Regional-reference-values.pdf

45 International Institute of Refrigeration. 2021. The Carbon Footprint of the Cold Chain, $7^{\text {th }}$ Informatory Note on 46 Refrigeration and Food. https://iifiir.org/en/fridoc/the-carbon-footprint-of-the-cold-chain-7-lt-sup-gt-th-lt-sup-gt47 informatory-143457 
IPCC. 1996. Climate Change 1995 - The Science of Climate Change: Contribution of Working Group I to the Second Assessment Report of the Intergovernmental Panel on Climate Change. Cambridge. Available at: https://www.ipcc.ch/ipccreports/sar/wg I/ipcc sar wg I full report.pdf

4 IPCC. 2000. Good practice guidance and uncertainty management in national greenhouse gas inventories. In: J.

5 Penman et al. (Eds.), IPCC National Greenhouse Gas Inventories Programme, Technical Support Unit, Hayama,

6 Japan. Available at: http://www.ipcc-nggip.iges.or.jp/public/gp/english/gpgaum_en.html

IPCC. 2006. 2006 IPCC Guidelines for National Greenhouse Gas Inventories, Prepared by the National Greenhouse Gas Inventories Programme, Eggleston H.S., Buendia L., Miwa K., Ngara T. \& Tanabe K. (eds). Published: IGES, Japan. Available at: https://www.ipcc-nggip.iges.or.jp/public/2006gl/vol5.html

JRC. European Commission. 2015. Monforti, F., Dallemand, J., Pascua, I., Motola, V., Banja, M., Scarlat, N., Medarac, H., Castellazzi, L., Labanca, N., Bertoldi, P., Pennington, D., Goralczyk, M., \& Schau, E., Saouter, E., \& Sala, S., Notarnicola, B., Tassielli, G., and Renzulli, P. Energy use in the EU food sector: State of play and opportunities for improvement.

Karl, K. and Tubiello, F.N. 2021a. Methods for Estimating Greenhouse Gas Emissions from Food Systems: Domestic Food Transport. Rome.

Karl, K. and Tubiello, F.N. 2021b. Methods for Estimating Greenhouse Gas Emissions from Food Systems: Food Systems Waste Disposal. Rome.

Mbow, C., C. Rosenzweig, L.G. Barioni, T.G. Benton, M. Herrero, M. Krishnapillai, E. Liwenga, P. Pradhan, M.G. Rivera-Ferre, T. Sapkota, F.N. Tubiello, Y. Xu, 2019: Food Security. In: Climate Change and Land: an IPCC special report on climate change, desertification, land degradation, sustainable land management, food security, and greenhouse gas fluxes in terrestrial ecosystems [P.R. Shukla, et al. (eds.)].

Pablo-Romero, María del P., Rafael Pozo-Barajas, and Rocío Yñiguez. 2017. "Global Changes in Residential Energy Consumption.” Energy Policy 101. Available at: https://doi.org/10.1016/j.enpol.2016.10.032.

Poore, J. \& Nemecek, T. 2018. Reducing Food's Environmental Impacts through Producers and Consumers. Science 360, no. 6392: 987-92. https://doi.org/10.1126/science.aaq0216.

Rosenzweig, C., Tubiello, F.N., Sandalow, D., Benoit, P. and Hayek, M.N., 2021. Finding and fixing food system emissions: the double helix of science and policy. Environmental Research Letters, 16(6).

Rosenzweig, C., Mbow, C., Barioni, L. G., Benton, T. G., Herrero, M., Krishnapillai, M., Liwenga, E. T., Pradhan, P., Rivera-Ferre, M. G., Sapkota, T., Tubiello, F. N., Xu, Y., Mencos Contreras, E., \& Portugal-Pereira, J. 2020. Climate change responses benefit from a global food system approach. Nature Food, 1(2), 94-97. https://doi.org/10.1038/s43016-020-0031-z

Saunois, M., Stavert, A. R., Poulter, B., Bousquet, P., Canadell, J. G., Jackson, R. B., Raymond, P. A., Dlugokencky, E. J., Houweling, S., Patra, P. K., Ciais, P., Arora, V. K., Bastviken, D., Bergamaschi, P., Blake, D. R., Brailsford, G., Bruhwiler, L., Carlson, K. M., Carrol, M., ... Zhuang, Q. 2020. The Global Methane Budget 2000-2017. Earth System Science Data, 12(3), 1561-1623. https://doi.org/10.5194/essd-12-1561-2020

Sims R.E.H. and Flammini A., 2014. Energy-smart food - technologies, practices and policies. Chapter 6 . Sustainable Energy Solutions in Agriculture. Taylor \& Francis Group, London, UK

Smith, P., Bustamante, M., Ahammad, H., Clark, H., Dong, H., Elsiddig, E .A., Haberl, H., Harper, R., House, J., Jafari, M., Masera, O., Mbow, C., Ravindranath, N. J., Rice, C. W., Robledo Abad, C., Romanovskaya, A., Sperling, F., and Tubiello, F. N. 2014. Agriculture, Forestry and Other Land Use (AFOLU), in Working Group III contribution to the IPCC 5th Assessment Report, Climate Change 2014: Mitigation of Climate Change, edited by: Edenhofer, O., Pichs-Madruga, R., Sokona, Y., Farahani, E., Kadner, S., Seyboth, K., Adler, A., Baum, I., Brunner, S., Eickemeier, P., Kriemann, B., Savolainen, J., Schlömer, S., von Stechow, C., Zwickel, T., and Minx, J. C., Cambridge University Press, Cambridge, UK, New York, NY, USA,

Tubiello, F. N., Salvatore, M., Rossi, S., Ferrara, A., Fitton, N., \& Smith, P. 2013. The FAOSTAT database of greenhouse gas emissions from agriculture. 8(1), 015009. https://doi.org/10.1088/1748-9326/8/1/015009

Tubiello, F.N., Rosenzweig, C., Conchedda, G., Karl, K., Gütschow, J., Xueyao, P., Obli-Laryea, G., Wanner, N., Qiu, S.Y., De Barros, J. and Flammini, A., 2021a. Greenhouse gas emissions from food systems: building the evidence base. Environmental Research Letters, 16(6), p.065007.

50 Tubiello, F.N.., Flammini, A., Karl, K., Obli-Laryea, G., Qiu, S.Y., Heiðarsdóttir, H., Pan, X., and Conchedda, G., 51 2021b. Methods for estimating greenhouse gas emissions from food systems. Part III: energy use in fertilizer 
manufacturing, food processing, packaging, retail and household consumption. FAO Statistics Working Paper 2129. Rome.

Tubiello, F. N., Conchedda, G., Wanner, N., Federici, S., Rossi, S., \& Grassi, G. 2021c. Carbon emissions and removals from forests: New estimates, 1990-2020. Earth System Science Data, 13(4), 1681-1691. https://doi.org/10.5194/essd-13-1681-2021

6 Tubiello, F.N., Karl, K., Flammini, A., Conchedda, G., and Obli-Laryea, G., 2021d. Food Systems Emissions

7 Shares, 1990-2019. Open access dataset, available at https://zenodo.org/record/5615082

8 UNFCCC. 2021. Nationally determined contributions under the Paris Agreement. Synthesis report by the 9 secretariat. Available at: https://unfccc.int/documents/306848

10 Wang, Lijun. 2014. "Energy Efficiency Technologies for Sustainable Food Processing." Energy Efficiency, vol. 7, 11 no. 5, pp. 791-810. Springer Link. doi:10.1007/s12053-014-9256-8.

12 Vermeulen, Sonja J., Bruce M. Campbell, and John S.I. Ingram. 2012. "Climate Change and Food Systems." 13 Annual Review of Environment and Resources 37, no. 1: 195-222. https://doi.org/10.1146/annurev-environ$14 \quad \underline{020411-130608}$. 


\begin{tabular}{lrrr}
\hline Process & $\mathbf{1 9 9 0}$ & $\mathbf{2 0 1 9}$ & Change \\
\hline Net Forest conversion & 4,392 & 3,058 & $-30 \%$ \\
\hline Enteric Fermentation & 2,494 & 2,823 & $13 \%$ \\
\hline Livestock Manure & 1,101 & 1,315 & $19 \%$ \\
\hline Household Consumption & 541 & 1,309 & $142 \%$ \\
\hline Waste Disposal & 984 & 1,278 & $30 \%$ \\
\hline On-farm energy use & 757 & 1,021 & $35 \%$ \\
\hline Retail & 128 & 932 & $631 \%$ \\
\hline Drained organic soils & 736 & 833 & $13 \%$ \\
\hline Rice Cultivation & 621 & 674 & $9 \%$ \\
\hline Fires & 558 & 654 & $17 \%$ \\
\hline Synthetic Fertilizers & 422 & 601 & $42 \%$ \\
\hline Transport & 327 & 586 & $79 \%$ \\
\hline Food Processing & 421 & 510 & $21 \%$ \\
\hline Fertilizers Manufacturing & 152 & 408 & $168 \%$ \\
\hline Packaging & 166 & 310 & $87 \%$ \\
\hline Crop Residues & 161 & 226 & $40 \%$ \\
\hline Forestland & $-3,391$ & $-2,571$ & $-24 \%$ \\
\hline
\end{tabular}

4

5 Table 1. GHG emissions ( $\mathrm{Mt} \mathrm{CO}_{2} \mathrm{eq}$ ) by agri-food systems component for all processes considered in this work.

6 Data on forestland removals are provided for completeness of land-based emissions available in FAOSTAT. 
https://doi.org/10.5194/essd-2021-389

Preprint. Discussion started: 8 November 2021

(c) Author(s) 2021. CC BY 4.0 License.

1

2

\begin{tabular}{l|llllllll}
\multicolumn{1}{l}{$\begin{array}{l}\text { Region } \\
\text { Farm }\end{array}$} & LUC & PPP & Total & \%PPP & $\begin{array}{l}\text { \%PPP } \\
\text { (1990) }\end{array}$ & $\begin{array}{l}\text { Highest } \\
\text { PPP }\end{array}$ & note \\
\hline Asia & 3.2 & 0.9 & 2.9 & 7.0 & $42 \%$ & $24 \%$ & 0.9 & Household \\
Africa & 1.1 & 1.2 & 0.4 & 2.7 & $14 \%$ & $16 \%$ & 0.2 & Household \\
South America & 1.0 & 1.1 & 0.3 & 2.4 & $12 \%$ & $6 \%$ & 0.1 & Waste \\
Europe & 0.9 & 0.1 & 1.1 & 2.1 & $55 \%$ & $26 \%$ & 0.4 & Retail \\
Northern America & 0.6 & 0.2 & 0.8 & 1.5 & $52 \%$ & $35 \%$ & 0.3 & Retail \\
Oceania & 0.2 & 0.0 & 0.1 & 0.3 & $23 \%$ & $11 \%$ & 0.0 & Retail
\end{tabular}

3

4

5 Table 2. Regional GHG emissions ( $\left.\mathrm{Gt} \mathrm{CO}_{2} \mathrm{eq}\right)$ by agri-food systems component, showing total food systems

6 emissions and percentage contribution of emissions form pre- and post-production processes. 1990 and 2019. The

7 last two columns show the largest sub-component of pre- and post-production emissions by region. 
https://doi.org/10.5194/essd-2021-389

Preprint. Discussion started: 8 November 2021

(c) Author(s) 2021. CC BY 4.0 License.

\begin{tabular}{r|llllll} 
Country & Farm-gate & LUC & PPP & Total & Max PPP & Note \\
\hline China & 792 & 0 & 1102 & 1894 & 469 & Household \\
India & 768 & 0 & 618 & 1386 & 205 & On-farm \\
Brazil & 553 & 663 & 144 & 1360 & 79 & Food Waste \\
Indonesia & 491 & 658 & 132 & 1281 & 76 & Food Waste \\
United States of America & 477 & 60 & 696 & 1232 & 292 & Retail \\
Russian Federation & 28 & 624 & 9 & 660 & 8 & Food Waste \\
Pakistan & 146 & 35 & 362 & 542 & 177 & Retail \\
Canada & 97 & 7 & 71 & 283 & 33 & Food Waste \\
Mexico & 115 & 96 & 81 & 274 & 20 & Retail \\
& & 15 & 116 & 246 & 56 & Food Waste
\end{tabular}

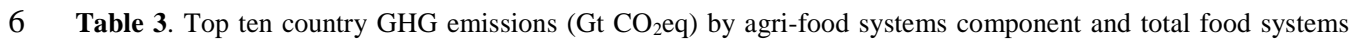

7 emissions, 2019. The last two columns show the dominant sub-component of pre- and post-production processes.

8

9 


\begin{tabular}{rrrrrrrrr} 
& \multicolumn{2}{c}{ Farm gate } & \multicolumn{2}{c}{ Land Use Change } & Supply Chains & \multicolumn{2}{c}{ Food Systems } \\
\cline { 2 - 11 } Africa & $\mathbf{1 9 9 0}$ & $\mathbf{2 0 1 9}$ & $\mathbf{1 9 9 0}$ & $\mathbf{2 0 1 9}$ & $\mathbf{1 9 9 0}$ & $\mathbf{2 0 1 9}$ & $\mathbf{1 9 9 0}$ & $\mathbf{2 0 1 9}$ \\
& $\mathbf{7 0 5}$ & 1139 & 1017 & 1220 & 323 & 388 & 2045 & 2747 \\
& $23 \%$ & $24 \%$ & $33 \%$ & $26 \%$ & $11 \%$ & $8 \%$ & $67 \%$ & $57 \%$ \\
\hline Asia & 2595 & 3250 & 1273 & 865 & 1223 & 2930 & 5091 & 7044 \\
& $25 \%$ & $11 \%$ & $12 \%$ & $3 \%$ & $12 \%$ & $10 \%$ & $49 \%$ & $24 \%$ \\
\hline Europe & 1603 & 854 & 88 & 83 & 589 & 1140 & 2280 & 2077 \\
& $16 \%$ & $13 \%$ & $1 \%$ & $1 \%$ & $6 \%$ & $17 \%$ & $23 \%$ & $31 \%$ \\
\hline North America & 538 & 574 & 175 & 156 & 376 & 777 & 1089 & 1507 \\
& $8 \%$ & $8 \%$ & $3 \%$ & $2 \%$ & $6 \%$ & $11 \%$ & $17 \%$ & $21 \%$ \\
\hline South America & 728 & 982 & 1974 & 1106 & 176 & 281 & 2878 & 2369 \\
& $23 \%$ & $30 \%$ & $64 \%$ & $34 \%$ & $6 \%$ & $9 \%$ & $93 \%$ & $72 \%$ \\
\hline Oceania & 267 & 223 & 65 & 16 & 42 & 71 & 374 & 309 \\
& $40 \%$ & $28 \%$ & $10 \%$ & $2 \%$ & $6 \%$ & $9 \%$ & $57 \%$ & $39 \%$ \\
\hline World & 6604 & 7214 & 4676 & 3503 & 2886 & 5827 & 14165 & 16544 \\
& $19 \%$ & $13 \%$ & $13 \%$ & $6 \%$ & $8 \%$ & $11 \%$ & $40 \%$ & $31 \%$ \\
\hline
\end{tabular}

5

6

7 Table 4. Regional GHG emissions $\left(\mathrm{Gt} \mathrm{CO}_{2} \mathrm{eq}\right)$ by agri-food systems component and total food systems emissions,

8 2019. The last two columns show the dominant sub-component of pre- and post-production processes. 


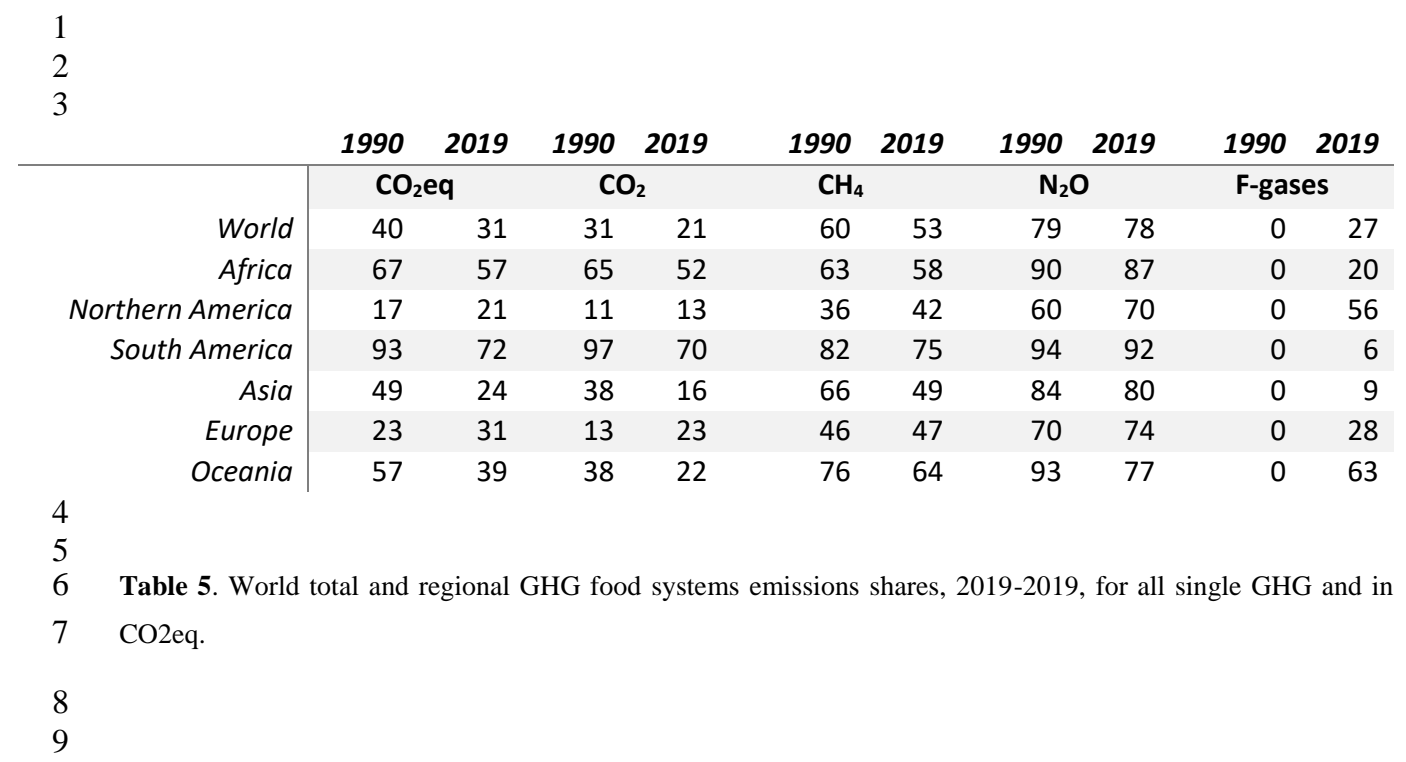




\section{FIGURE LEGENDS}

2

3 Figure 1. Mapping of emissions across agri-food systems. Left-hand panel: IPCC sectors and processes used in

national GHG emissions inventories. Right-hand panel: food and agriculture sectors and categories aligned to FAO's definitions.

Figure 2. World-total GHG emissions from agri-food systems, 1990-2019. Color bars show contributions by emissions within the farm gate (yellow); land use change (green) and pre- and post- production along food supply chains (blue). Source: FAOSTAT (FAO, 2021). Also shown are emissions per capita (authors' own calculations).

Figure 3. World total 2019 GHG emission from agri-food systems, showing contributions on agricultural land (left panel) and from pre- and post- production along food supply chains (right panel). Net removals on forest land are also shown, for completeness. The sum of emissions from agricultural land and forest land correspond to the IPCC AFOLU category. Source: FAOSTAT (FAO, 2021).

Figure 4. Total GHG emission from agri-food systems by FAO regions, 2019. Color bars show contributions by emissions within the farm gate (yellow); land use change (green) and pre- and post- production along food supply chains (blue). Source: FAOSTAT (FAO, 2021).

Figure 5. Total GHG emission from agri-food systems by country, top ten emitters, 2019. Color bars show contributions by emissions within the farm gate (yellow); land use change (green) and pre- and post- production along food supply chains (blue). Source: FAOSTAT (FAO, 2021).

Figure 6. Top panel: Agri-food sytems emissions $\left(\mathrm{GtCO}_{2} \mathrm{eq} \mathrm{yr}^{-1}\right)$; Bottom panel: shares of agri-food systems in total anthropogenic emissions (\%). Data shown by region, 1990-2019. Color bars show contributions component: farm gate (yellow); land use change (green) and pre- and post- production along food supply chains (blue). Source: FAOSTAT (FAO, 2021). 


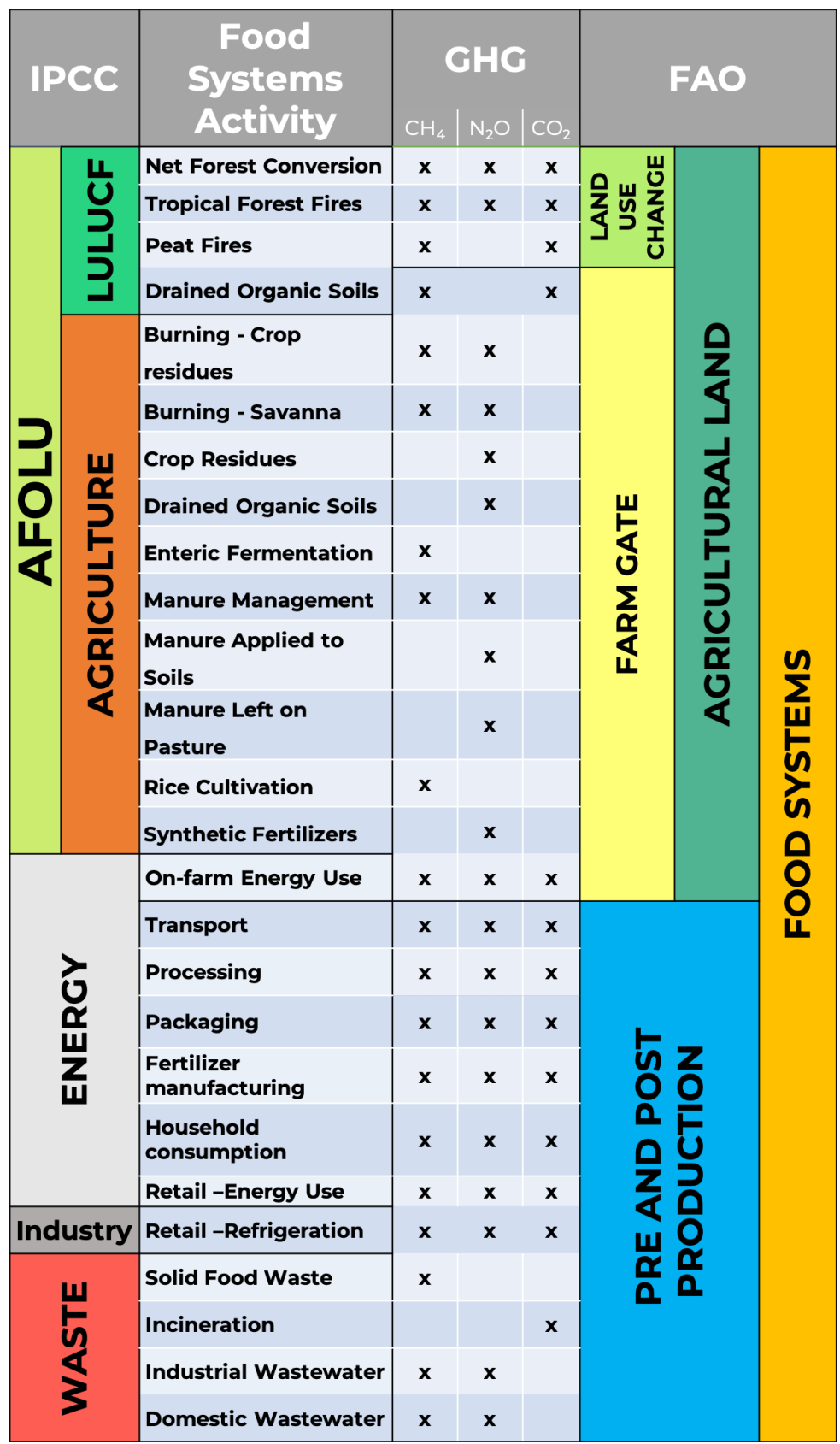

Figure 1. Mapping of emissions across agri-food systems. Left-hand panel: IPCC sectors and processes used in national GHG emissions inventories. Right-hand panel: food and agriculture sectors and categories aligned to FAO's definitions 


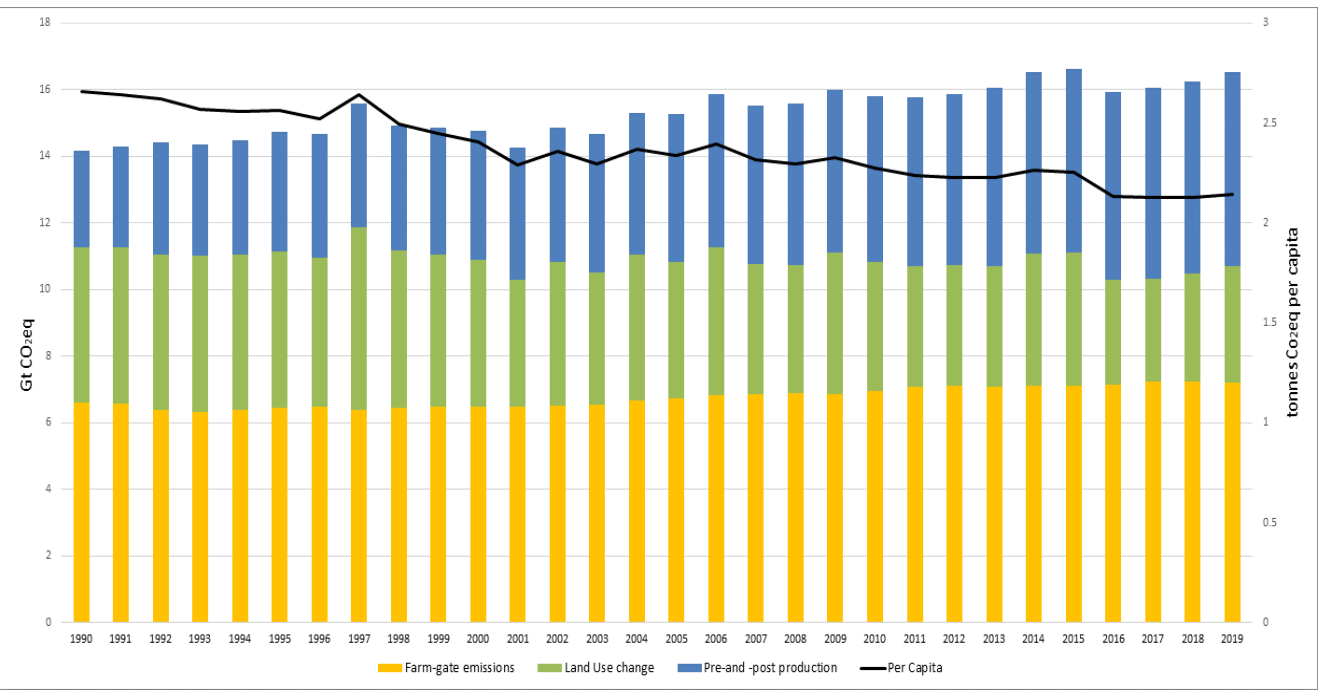

3

Figure 2. World-total GHG emissions from agri-food systems, 1990-2019. Color bars show contributions by emissions within the farm gate (yellow); land use change (green) and pre- and post- production along food supply chains (blue). Source: FAOSTAT (FAO, 2021). Also shown are emissions per capita (authors' own calculations). 
https://doi.org/10.5194/essd-2021-389

Preprint. Discussion started: 8 November 2021

(c) Author(s) 2021. CC BY 4.0 License.

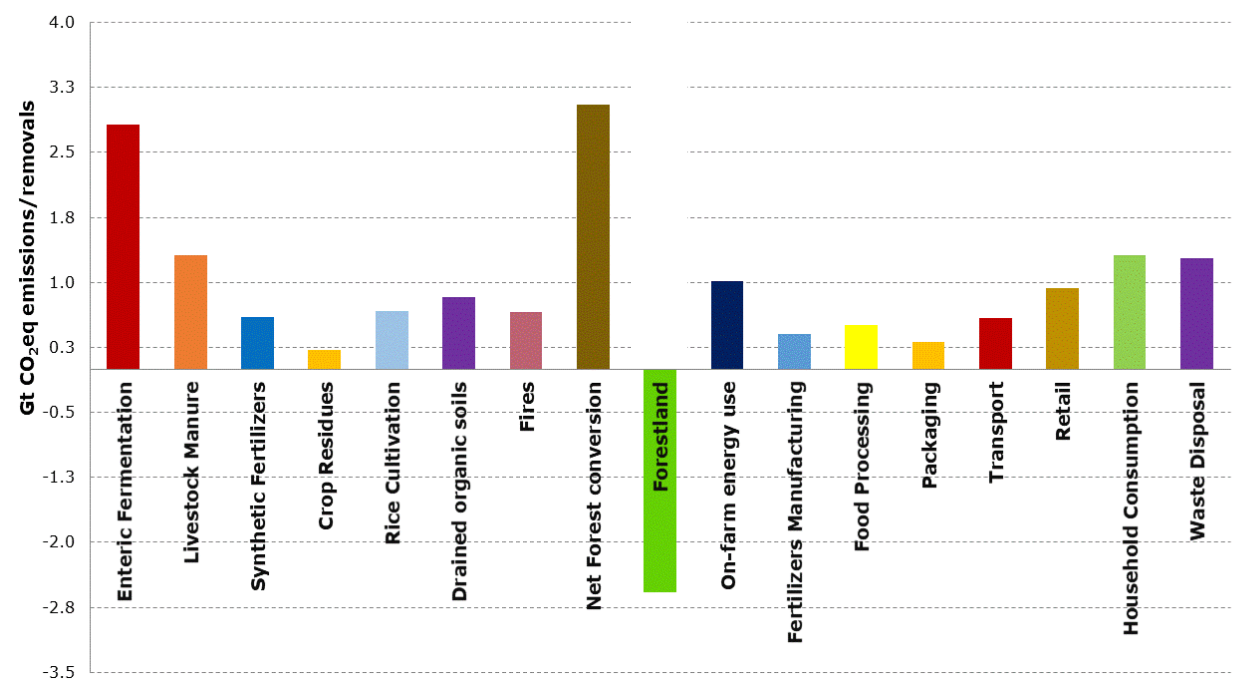

2 Figure 3. World total 2019 GHG emission from agri-food systems, showing contributions on agricultural land (left 3 panel) and from pre- and post- production along food supply chains (right panel). Net removals on forest land are also 4 shown, for completeness. The sum of emissions from agricultural land and forest land correspond to the IPCC AFOLU 5 category. Source: FAOSTAT (FAO, 2021). 
https://doi.org/10.5194/essd-2021-389

Preprint. Discussion started: 8 November 2021

(c) Author(s) 2021. CC BY 4.0 License.

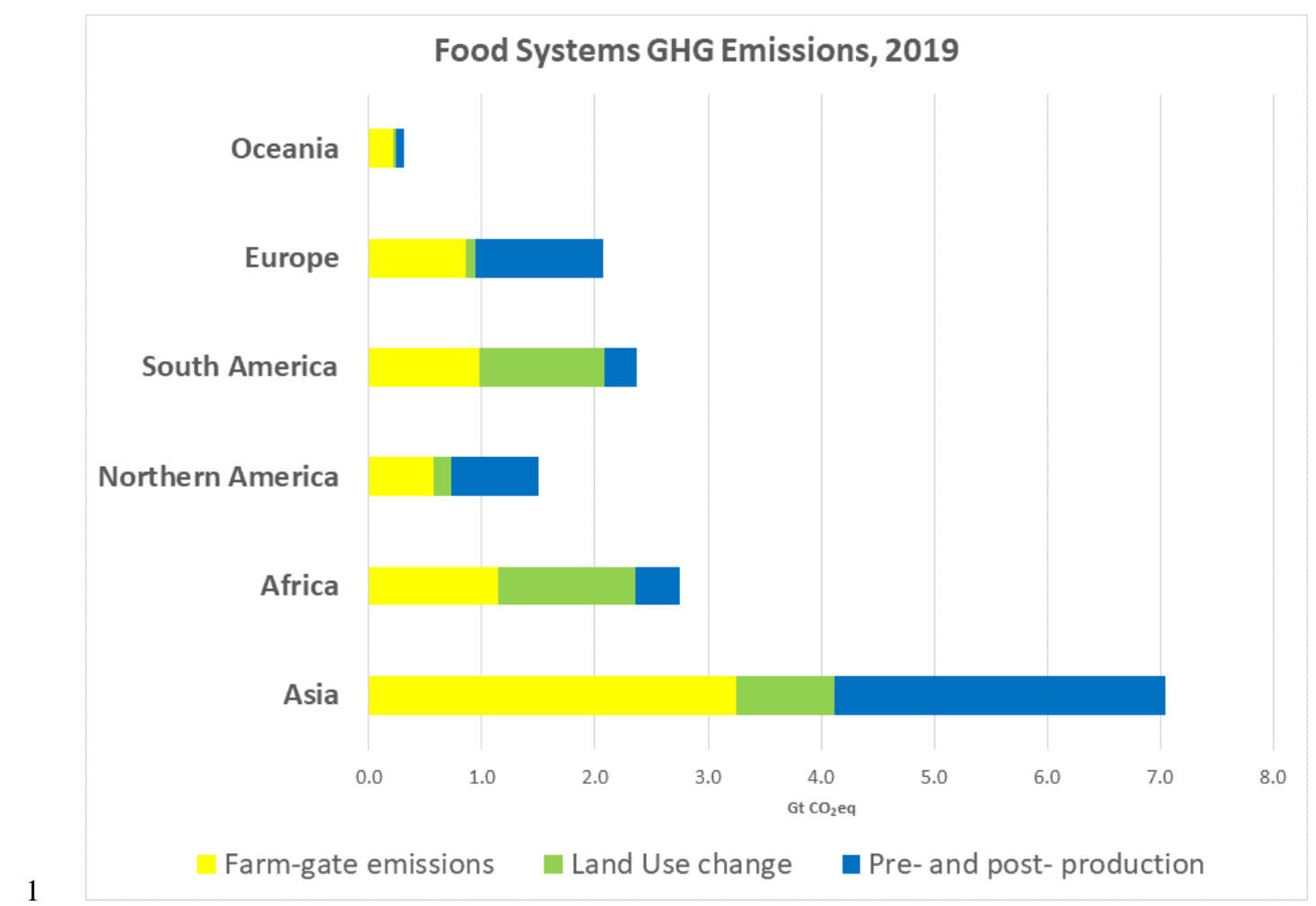

2

3 Figure 4. Total GHG emission from agri-food systems by FAO regions, 2019. Color bars show contributions by

4 emissions within the farm gate (yellow); land use change (green) and pre- and post- production along food supply chains

5 (blue). Source: FAOSTAT (FAO, 2021).

6 
https://doi.org/10.5194/essd-2021-389

Preprint. Discussion started: 8 November 2021

(c) Author(s) 2021. CC BY 4.0 License.

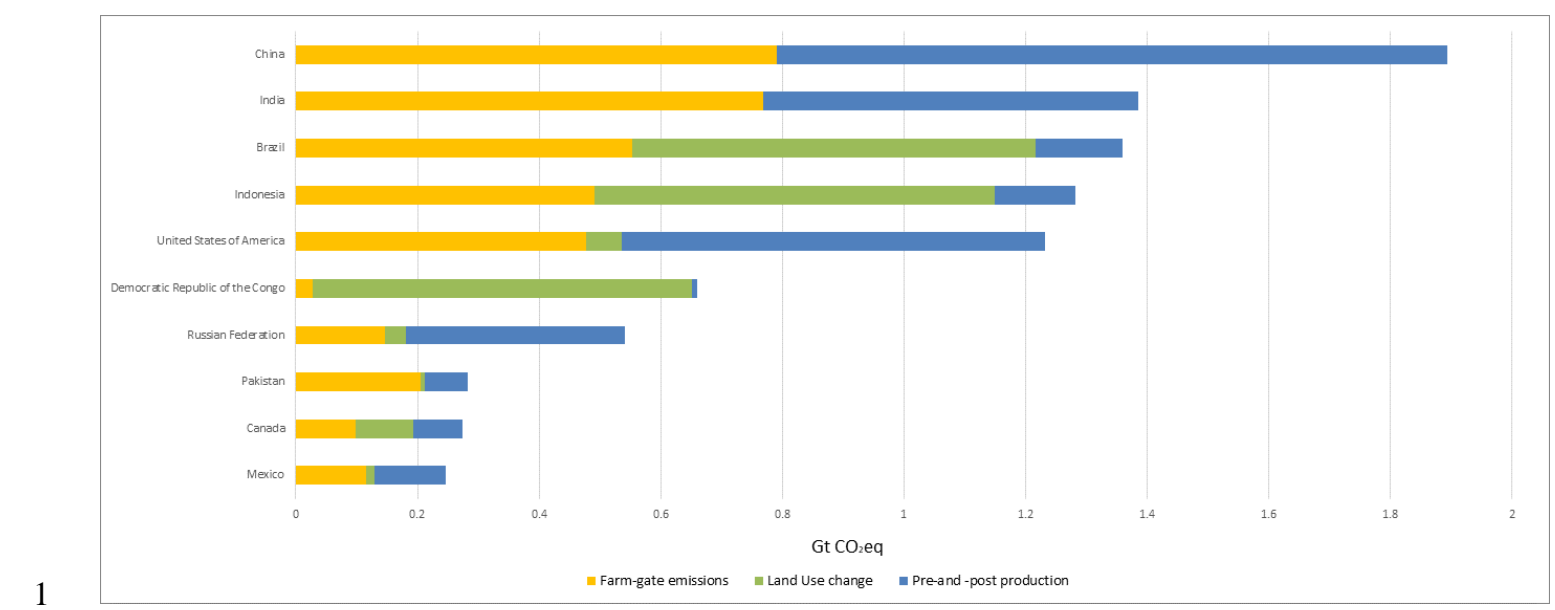

2 Figure 5. Total GHG emission from agri-food systems by country, top ten emitters, 2019. Color bars show contributions

3 by emissions within the farm gate (yellow); land use change (green) and pre- and post- production along food supply

4 chains (blue). Source: FAOSTAT (FAO, 2021). 
https://doi.org/10.5194/essd-2021-389

Preprint. Discussion started: 8 November 2021

(c) Author(s) 2021. CC BY 4.0 License.
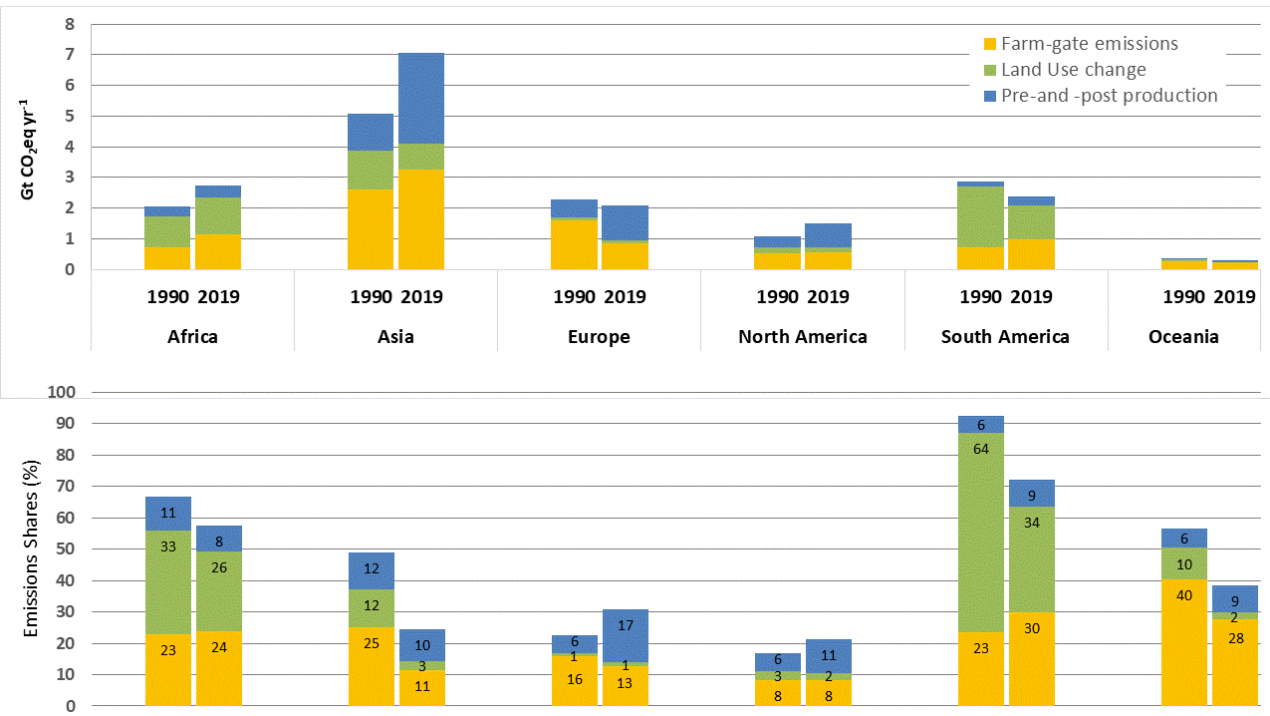

2

3 Figure 6. Top panel: Agri-food systems emissions ( $\left.\mathrm{GtCO}_{2} \mathrm{eq} \mathrm{yr}^{-1}\right)$; Bottom panel: shares of agri-food systems in total 4 anthropogenic emissions (\%). Data shown by region, 1990-2019. Color bars show contributions component: farm gate 5 (yellow); land use change (green) and pre- and post- production along food supply chains (blue). Source: FAOSTAT 6 (FAO, 2021). 